\title{
Effects of cilostazol in kidney and skeletal striated muscle of Wistar rats submitted to acute ischemia and reperfusion of hind limbs ${ }^{1}$
}

\author{
Efeitos do cilostazol em rim e musculatura estriada esquelética de ratos Wistar submetidos à \\ isquemia aguda e reperfusão de membros posteriores
}

\begin{abstract}
Antonio Augusto Moreira Neto ${ }^{I}$, Sylvio Sebastião de Souza Júnior ${ }^{I I}$, Vera Luíza Capelozzi' ${ }^{\mathrm{III}}$, Edwin Roger Parra-Cuentas ${ }^{\mathrm{IV}}$, Aurelino Fernandes Schmidt Júniorv, Acácio Francisco Netovi, Olavo Ribeiro Rodrigues ${ }^{\mathrm{VII}}$

${ }^{\mathrm{I}} \mathrm{PhD}$, Assistant Professor, Department of Surgery, Vascular Surgery Division, UMC, Mogi das Cruzes-SP, Brazil. Main author. Responsible for conception, design, intellectual and scientific content of the study.

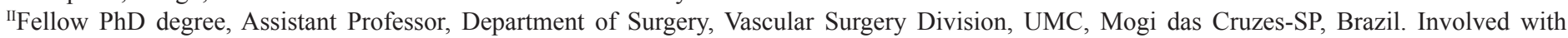
technical procedures, acquisition of data and critical revision.

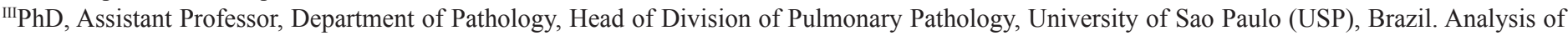
data.

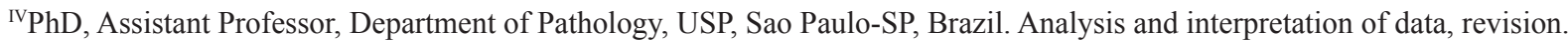

${ }^{v} \mathrm{PhD}$, Assistant Professor, Department of Surgery, Thoracic Surgery Division, UMC, Mogi das Cruzes-SP, Brazil. Manuscript writing, critical revision. ${ }^{v} \mathrm{PhD}$, Associate Professor, Department of Surgery, Head Division of Vascular Surgery, UMC, Mogi das Cruzes-SP, Brazil. Critical revision.

${ }^{\mathrm{VII}} \mathrm{PhD}$, Associate Professor, Department of Surgery, Head Division of Thoracic Surgery, UMC, Mogi das Cruzes-SP, Brazil. Conception and design of the study, critical revision.
\end{abstract}

\begin{abstract}
PURPOSE: To investigate the effect of cilostazol, in kidney and skeletal muscle of rats submitted to acute ischemia and reperfusion. METHODS: Fourty three animals were randomized and divided into two groups. Group I received a solution of cilostazol (10 mg/ $\mathrm{Kg}$ ) and group II received saline solution $0.9 \%$ (SS) by orogastric tube after ligature of the abdominal aorta. After four hours of ischemia the animals were divided into four subgroups: group IA (Cilostazol): two hours of reperfusion. Group IIA (SS): two hours of reperfusion. Group IB (Cilostazol): six hours of reperfusion. Group IIB (SS) six hours of reperfusion. After reperfusion, a left nephrectomy was performed and removal of the muscles of the hind limb. The histological parameters were studied. In kidney cylinders of myoglobin, vacuolar degeneration and acute tubular necrosis. In muscle interstitial edema, inflammatory infiltrate, hypereosinophilia fiber, cariopicnose and necrosis. Apoptosis was assessed by immunohistochemistry for cleaved caspase-3 and TUNEL.
\end{abstract}

RESULTS: There was no statistically significant difference between groups.

CONCLUSION: Cilostazol had no protective effect on the kidney and the skeletal striated muscle in rats submitted to acute ischemia and reperfusion in this model.

Key words: Ischemia. Reperfusion. Immunohistochemistry. Histology. Rats.

\section{RESUMO}

OBJETIVO: Investigar o efeito do cilostazol no rim e na musculatura esquelética de ratos submetidos à isquemia aguda e reperfusão. MÉTODOS: Quarenta e três animais foram aleatoriamente distribuídos em dois grupos. Grupo I recebeu solução de cilostazol (10 $\mathrm{mg} / \mathrm{Kg}$ ) e Grupo II recebeu solução fisiológica a $0,9 \%$ (SF), após ligadura da aorta abdominal. Decorridas quatro horas de isquemia os animais foram distribuídos em quatro subgrupos: Grupo IA (Cilostazol): duas horas de reperfusão. Grupo IIA (SF): duas horas de reperfusão. Grupo IB (Cilostazol): seis horas de reperfusão. Grupo IIB (SF): seis horas de reperfusão. Após a reperfusão, realizou-se nefrectomia esquerda e a retirada da musculatura de membro posterior. Os parâmetros histológicos estudados em rim foram cilindros de mioglobina, degeneração vacuolar e necrose tubular. Em músculo foram edema, infiltrado inflamatório, hipereosinofilia de fibras, cariopicnose e necrose. A apoptose foi avaliada por imunohistoquímica, através da caspase-3 clivada e TUNEL.

RESULTADOS: Não houve diferença estatisticamente significante entre os grupos estudados.

CONCLUSÃO: O cilostazol não teve efeito protetor sobre o rim e sobre a musculatura estriada esquelética em ratos Wistar submetidos à isquemia aguda e reperfusão no modelo estudado.

Descritores: Isquemia. Reperfusão. Imunoistoquímica. Histologia. Ratos. 


\section{Introduction}

The reperfusion syndrome is characterized by metabolic acidosis, hyperkalemia by the loss of intracellular potassium, increased serum creatine kinase and myoglobin with myoglobinury ${ }^{1}$. May result in acute renal failure: coagulation disorders, accumulation of extracellular fluid and acute pulmonary distress $^{2}$.

With the acute ischemia, initiating anaerobic metabolism, glycogen with transformation into lactate, leading to decreased production of adenosine triphosphate (ATP), which alters the permeability of the cell muscle, allowing the output of potassium and myoglobin and entry Sodium and calcium célula ${ }^{3}$.

The cell damage occurs only after an interval of thirty minutes of ischemia and irreversible changes in skeletal muscle occur after four to six hours of ischemia. Ischemia can lead to cell death by necrosis or apoptosis ${ }^{4}$.

The caspases are a group of protease essential for apoptosis, which makes irreversible cleavage of DNA. The cascade activation of caspases can be triggered by many factors, such as the presence of superoxide, which is a derivative of the mass muscular ischemia ${ }^{5}$.

After reperfusion muscle, is released into the circulation of acid metabolites and products of cell destruction that cause significant metabolic alterations, such as metabolic acidosis and hyperkalemia ${ }^{5}$. The more severe change is due to precipitation of myoglobin in the renal tubules in acid environment, causing acute tubular necrosis ${ }^{6}$.

Treatment of acute ischemia reperfusion is only the affected territory reperfusion of which may lead to ischemia and reperfusion syndrome.

Many times reperfusion cannot be performed immediately after the onset of ischemia, since there is a very variable period of time between the first symptoms of the disease and emergency medical care.

Cilostazol is an antiplatet drug and vasodilator with antimitogenics and cardiotonic actions intended to reduce the symptoms of peripheral vascular disease, intermittent claudication ${ }^{7}$ and prevention of recurrent cerebral stroke ${ }^{8}$.

We hypothesize that cilostazol inhibits platelet aggregation and promoting vasodilation could decrease the deleterious effects of ischemia and reperfusion syndrome. If administered at the onset of ischemia could reduce acute ischemic events, and consequently reduce renal injury after reperfusion.

The objective of this study is to assess the effect of cilostazol in the kidney and skeletal striated muscle of Wistar rats submitted to acute ischemia and reperfusion of hind limbs, since no experimental models in animals studies on the effectiveness of cilostazol in acute ischemia and reperfusion have been reported.

\section{Methods}

Forty three male Wistar rats aged ten months and average weight of $300 \mathrm{~g}$ were used.

This study was approved by the Ethics Committee for Animal Experimentation and Manipulation (CEMEA) on 10.03.2008 and according to Federal Law No. 11.794, of October 8, 2008, and Decree No. 6689 of July 15, 2009 which regulated Law 11,794.

The experiment was developed at the Center for Technological Research (NPT) of Mogi das Cruzes University in the period from July/2008 to October $/ 2010$.

\section{Surgical technique}

The animals were anesthetized and placed an orogastric tube.

Laparotomy was performed in $4 \mathrm{~cm}$ long. The abdominal aorta was ligated just below the renal artery with propylene 7.09.

Proceeded to divided into two randomly groups:

Group I (Cilostazol) - 21 animals, received by the tube solution of cilostazol (Cebralat ${ }^{\circledR}$, Libbs) at a concentration of 1 $\mathrm{mg} / \mathrm{ml}$ in $10 \mathrm{mg} / \mathrm{kg}$.

Group II (Sham) - 22 animals: received $10 \mathrm{ml} / \mathrm{kg}$ saline solution $0.9 \%$.

The solutions were administered immediately after aortic ligature.

The effectiveness of aortic ligature was confirmed by the appearance of pallor, cyanosis and decreased temperature on their hind legs for thermometry. The absence of pulse and flow in the aorta below the ligature was confirmed by intraoperative Dopplermetry.

\section{Ischemic time}

After aortic ligature, started to measure ischemia time and proceeded to the closure of the laparotomy.

After four hours of ischemia relaparotomy was performed in order to remove the aortic ligature and then, closed. 


\section{Reperfusion time}

After removing aortic ligature, started to measure time of reperfusion.

Two animals were excluded from the previous steps of the experiment because they died before the final reperfusion time. Forty one animals underwent a second phase, remaining in the study.

Proceeded to the distribution of animals in four groups according to the time of reperfusion:

Group IA: 11 animals that received cilostazol with reperfusion time of two hours.

Group IIA: 11 animals receiving saline solution $0.9 \%$, with time of two hours of reperfusion.

Group IB: nine animals receiving cilostazol with reperfusion time of six hours.

Group IIB: ten animals receiving saline solution 0.9\%, with time of six hours of reperfusion.

\section{Kidney and muscle harvesting and euthanasia}

The animals were anesthetized, a left nephrectomy was performed, and the hind limb muscles harvested and proceded the euthanasia.

The kidney and muscles of the left hind limb were divided into two parts, fixed in peraformaldehyde $10 \%$. One part was designed to histological analysis and the other for immunohistochemical study.

\section{Histological and immunohistochemical analysis}

The histological changes were examined in muscle: interstitial edema, inflammatory infiltrate, hypereosinophilia fiber, cariopicnose and necrosis (Figure 1). In kidney: presence of myoglobin cylinders, vacuolar degeneration of tubular cells and acute tubular necrosis (Figure 2$)^{5}$.

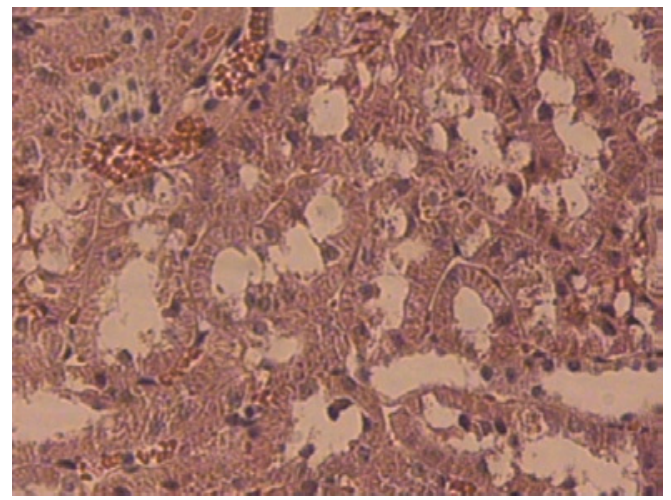

FIGURE 1 - Photomicrograph of histological section renal (440x magnification).

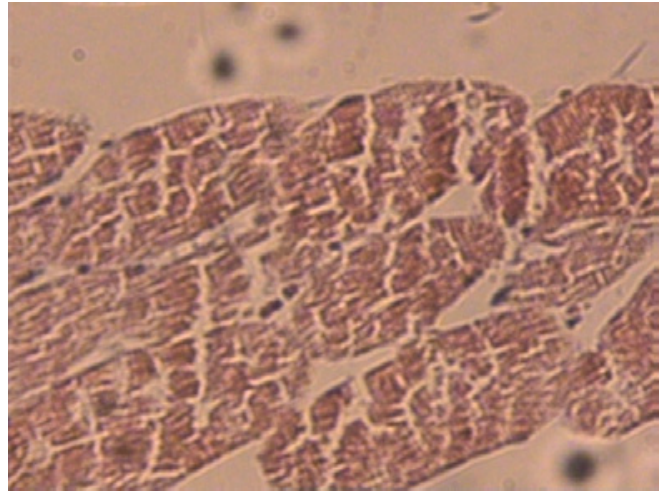

FIGURE 2 - Photomicrograph of histological section muscle (440x magnification).

For histological analysis were examined 10 microscopic fields non-coincident at 440x magnification of each sample.

The results of the histological analysis were expressed in a semi-quantitative percentage as the ratio of expression changes observed in the total:

$$
\begin{aligned}
& 0=\text { absent; } \\
& 1=\text { less than } 10 \% ; \\
& 2=11 \% \text { to } 25 \% ; \\
& 3=26 \% \text { to } 50 \% ; \\
& 4=\text { more than } 51 \% .
\end{aligned}
$$

The presence of apoptosis was evaluated by immunohistochemical expression of cleaved caspase 3 and TUNEL (TdT mediated dUTP nick endlabeling).

A sample of each animal resulted in two slide sections for the immunohistochemical analysis.

To determine the levels of immunohistochemical expression we used the technique of counting poins. We used a microscope equipped with an eyepiece and a grid of 50 rows and 100 points by 440x magnification. We examined 10 non-coincident microscopic fields on each piece to quantify all the points that fell on the stained portions, totaling 1000 points covering an area of $62.500 \mu \mathrm{m}^{2}$ per field of study. Points falling on stained areas represent the proportion of positively stained cells in the tissue $\operatorname{area}^{10}$ (Figure 3).

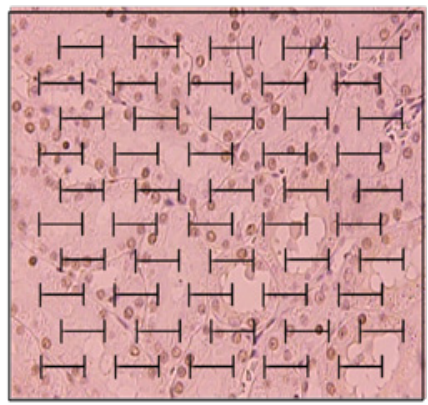

FIGURE 3 - Photomicrograph of the technique for measuring the expression of cleaved caspase-3 in kidney reticulum (440x magnification). 
The results of histological analysis and expression of immunohistochemical markers were tested using non-parametric Mann-Whitney (Wilcoxon Rank-Sum Test) for two independent samples, $\mathrm{p} \leq 0.05$ for significance. It was also made a graph of the $95 \%$ confidence interval of the mean for immunohistochemistry between groups with six hours of reperfusion.

\section{Results}

\section{Histological evaluation}

Histological changes observed in muscle and kidney that received cilostazol compared to control group showed no significant differences in two and six hours of reperfusion.

\section{Immunohistochemical evaluation}

The expression of cleaved caspase 3 in the kidney and TUNEL expression in the kidney and muscle are shown in Table 1 (next page).

The results showed that the total number of cells undergoing apoptosis quantified by cleaved caspase 3 and TUNEL was lower in the kidneys of animals that received cilostazol with six hours of reperfusion, however these differences were not statistically significant (Figures 4 and 5).

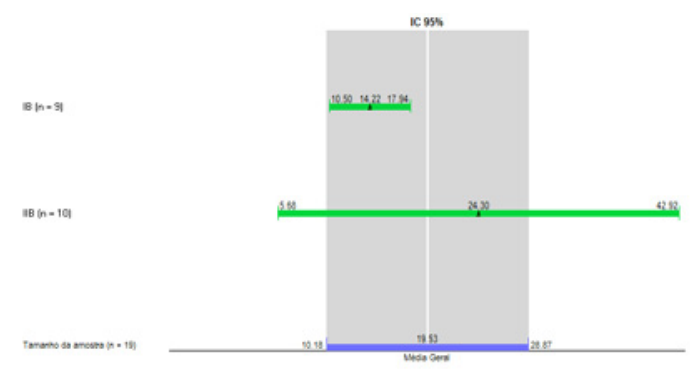

FIGURE 4 - Chart of $95 \%$ confidence interval of the average of groups of six hours of reperfusion: caspase- 3 cleaved in the kidney.

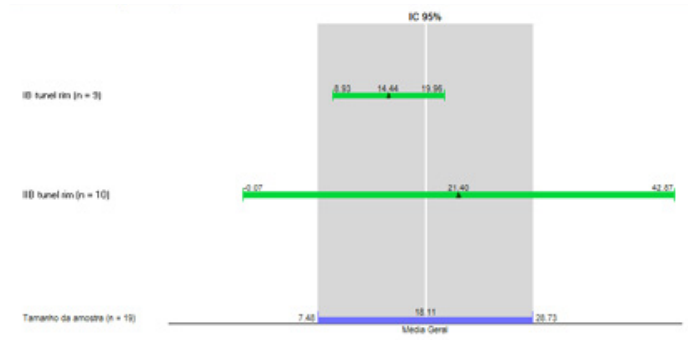

FIGURE 5 - Chart of $95 \%$ confidence interval of the average of groups of six hours of reperfusion: TUNEL in the kidney.

\section{Discussion}

The Cilostazol has been widely used in the treatment of chronic peripheral arterial disease and in treatment of ischemic coronary artery disease due to its antiplatelet and vasodilatation properties $^{7}$.

The therapeutic use of cilostazol in acute ischemia and its role in prevention of reperfusion syndrome has not been recommended. The lack of randomized controlled studies, using cilostazol in ischemia and reperfusion in rat kidney and muscle, we have motivated the design of this research. In this study it was hypothesized that cilostazol might have efficacy in treating acute ischemia and would decrease the metabolic syndrome of reperfusion protects target organs such as muscle and kidney.

Experimental studies have demonstrated that cilostazol obtained a protective effect against ischemic injury in animal models when used in another organs than skeletal muscle and kidneys ${ }^{11-13}$.

Several experimental studies had model and design similar to our study to investigate the effectiveness of other drugs in ischemia and reperfusion ${ }^{6,15,16}$.

A recent experimental study demonstrated that cilostazol reduces the oxidative stress of ischemia and reperfusion in rats subjected to 45 minutes of spinal cord ischemia by clamping the aorta and a reperfusion period of 48 hours. The biochemical and histopathological analysis of the treated animals at a dose of cilostazol $20 \mathrm{mg} / \mathrm{kg}$ orally for three days before spinal cord ischemia, demonstrated a reduction in neurological damage and a reduction of oxidative stress ${ }^{16}$.

The tissue injury caused by ischemia and reperfusion is described as early onset, and studies have shown that histological changes are observable by microscopy after four hours of ischemia and 15 minutes of reperfusion ${ }^{14}$.

In this study, histological changes due to ischemia and reperfusion were observed in the kidney and striated muscle in similar intensity in the animals receiving cilostazol and those who received only saline solution. These changes were independent of reperfusion time, since it did not differ significantly in the two groups and underwent six hours of reperfusion.

The expression of cleaved caspase $3^{18}$ and TUNEL ${ }^{19}$ for quantification of apoptosis currently have been used.

The expression of cleaved caspase 3 and TUNEL was lower in the cilostazol group with six hours of reperfusion, but not statistically significant. Therefore these results suggest that cilostazol could have a positive effect to reduce renal apoptosis in later periods of reperfusion. 
TABLE 1 - Expression of cleaved caspase 3 (kidney) and TUNEL (kidney and muscle) in the groups with six hours of reperfusion.

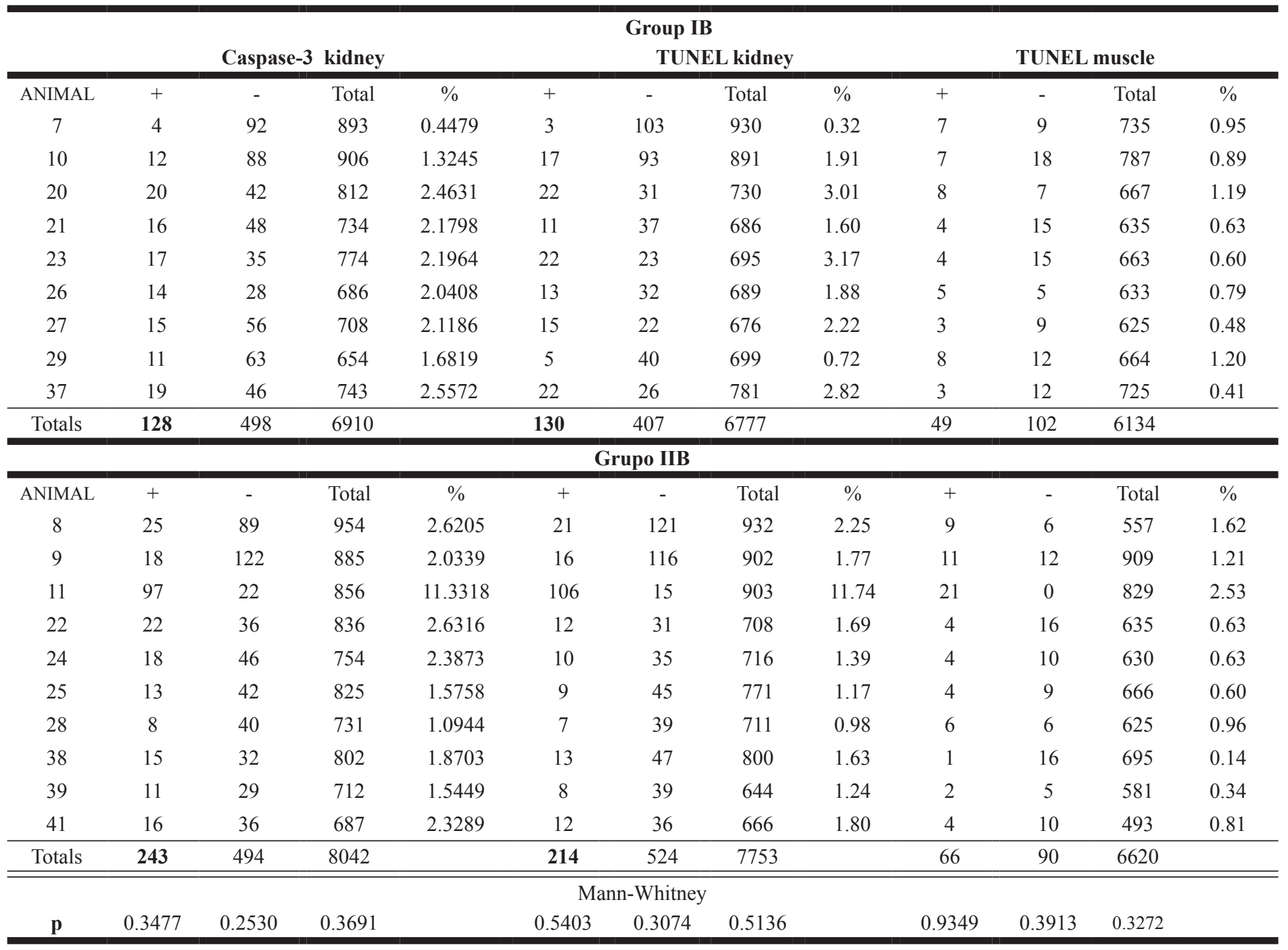

Another hypothesis could be due to the number of subjects used, which the analysis of a few animals per group, had no power to find statistically significant differences.

\section{Conclusion}

Cilostazol had no protective effect on the kidney and the skeletal striated muscle in rats submitted to acute ischemia and reperfusion in this model.

\section{References}

1. Haimovici H. Peripheral arterial embolism. A study of 330 unselected cases of embolism to the extremities. Angiology. 1950;1:1-20.

2. Blaisdell FW. The reperfusion syndrome. Microcirc Endothelium Lymphatics. 1989;5(3-5):127-41.

3. Silveira M, Yoshida SB. Isquemia e reperfusão em músculo esquelético. J Vasc Br. 2004;3(4):367-78.

4. Badhwar A, Dungey AA, Harris KA. Limitations of ischemic tolerance in oxidative skeletal muscle: perfusion vs tissue protection. J Surg Res. 2003;109:62-7.

5. Lockshin RA. An attempt to understand the multiparametric control of the initiation of apoptosis. Apoptosis. 2008;13(1):1195-7.

6. Teruya R, Fagundes DJ, Oshima CTF, Brasileiro JL, Marks G, Ynouye CM, Simões MJ. The effects of pentoxifylline into the kidneys of rats in a model of unilateral hindlimb ischemia/ reperfusion injury. Acta Cir Bras. 2008;23(1):29-35.

7. Akiyama H, Kudo S, Shimizu T. The absorption, distribution and excretion of a new antithrombotic and vasodilating agent, cilostazol, in rat, rabbit, dog and man. Arzneimittelforschung. 1985;35(7A):1124-32.

8. Rowlands TE, Donnelly R. Medical therapy for intermittent claudication. Eur J Vasc Endovasc Surg. 2007;34(3):314-21.

9. Huang Y, Cheng Y, Wu J, Li Y, Xu E, Hong Z. Cilostazol as an alternative to aspirin after ischaemic stroke: a randomised, doubleblind, pilot study. Lancet Neurol. 2008;7(6):494-9.

10. Francisco Neto A, Silva JCCB, Fagundes DJ, Percário S, Novo NF, Juliano Y, Moreira Neto AA. Estudo das alterações oxidativas, da capacidade antioxidante total e do óxido nítrico, em ratos 
submetidos à isquemia e reperfusão de membros posteriores. Acta Cir Bras. 2005;20(2):134-9.

11. Gundersen HJ, Bendtsen TF, Korbo L, Marcussen N, Moller A, Nielsen K. Some new, simple and efficient stereological methods and their use in pathological research and diagnosis. APMIS. 1988;96(5):379-94.

12. Fukusawa $M$, Nishida $H$, Sato $T$, Miyazaki $M$, Nakaya $H$ [4-(1-Cyclohexyl-1H-tetrazol-5-yl)butoxy]-3,4-dihydro-2-(1H) quinolinone (cilostazol), a phosphodiesterase type 3 inhibitor, reduces infarct size via activation of mitochondrial $\mathrm{Ca} 2+-$ activated $\mathrm{K}+$ channels in rabbit hearts. $\mathrm{J}$ Pharmacol Exp Ther. 2008;326(1):100-4.

13. Lee JH, Park SY, Shin YW, Hong KW, Kim CD, Sung SM, Kim KY, Lee WS. Neuroprotection by cilostazol, a phosphodiesterase type 3 inhibitor, against apoptotic white matter changes in rat after chronic cerebral hypoperfusion. Brain Res. 2006;1082(1):182-91.

14. Iba T, Kidokoro A, Fukunaga M, Takuhiro K, Ouchi M, Ito Y. Comparison of the protective effects of type III phosphodiesterase (PDE3) inhibitor (cilostazol) and acetylsalicylic acid on intestinal microcirculation after ischemia reperfusion injury in mice. Shock. 2006;26(5):522-6.

15. Brasileiro JL, Fagundes DJ, Miiji LON, Oshima CTF, Teruya R, Marks G, Inouye CM, Santos MA. Isquemia e reperfusão de músculo sóleo de ratos sob ação da pentoxifilina. J Vasc Bras. 2007;6(1):5063.

16. Francischetti I, Maffei FHA, Bitu-Moreno J, Fuhrmann Neto M, Coelho MPV, Kai FHT, Sequeira JL, Yoshida WB. Ação do ácido trissódio-cálcio-dietileno-triaminopentaacético (CaNa3DTPA) nas lesões de isquemia-reperfusão em membro posterior de rato. Acta Cir Bras. 2002;17(5):332-41

17. Sahin MA, Onan B, Guler A, Oztas E, Uysal B, Arslan S, Demirkilic U, Tatar H. Cilostazol, a type III phosphodiesterase inhibitor, reduces ischemia/reperfusion-induced spinal cord injury. Heart Surg Forum. 2011;14(3):E171-7.

18. Lee YS, Kang YJ, Kim HJ, Park MK, Seo HG, Lee JH. Higenamine reduces apoptotic cell death by induction of heme oxygenase-1 in rat myocardial ischemia-reperfusion injury. Apoptosis. 2006;11(7):1091-100.

19. Gavrieli Y, Sherman Y, Bem-Sasson AS. Identification of programmed cell death in situ via specific labeling of nuclear DNA fragmentation. J Cell Biol. 1992;119(3):493-501.

\section{Correspondence:}

Antonio Augusto Moreira Neto

Rua Alfredo Cardoso, 18

08710-280 Mogi das Cruzes - SP Brasil

Tel.: (55 11)4799-0440

femareis@yahoo.com.br

Received: June 21, 2012

Review: August 23, 2012

Accepted: September 20, 2012

Conflict of interest: none

Financial source: none

${ }^{1}$ Research performed at Center for Technological Research (NPT), Mogi das Cruzes University (UMC), Sao Paulo-SP, Brazil. 